\section{Surface Complexation Model for the Heavy Metal Adsorption on Natural Sediment}

\author{
XIANGHUA WEN, * QING DU, AND \\ HONGXIAO TANG \\ SKLEAC, Research Center for Eco-Environmental Sciences, \\ Chinese Academy of Sciences (RCEES), P.O. Box 2871, \\ Beijing 100085, People's Republic of China
}

Surface complexation models (SCM s) have been successfully used to describe metal ion adsorption on pure mineral materials. However, such models have rarely been applied to model adsorption on natural materials. In this study, the surface complexation model approach was used to describe the surface properties and adsorption behavior of natural aquatic sediment. Three typic al versions of the surface complexation model were used: constant capacitance model (CCM), diffuse layer model (DLM), and triple layer model (TLM). All the model parameters were determined on the basis of the experimental data of the potentiometric titration and the metal adsorption isotherm using LeAn River (China) sediment. The experimental data of the adsorption edges w ere used to verify the performance of the models. This work indicated that all three models can simulate the experimental results very well. In predicting the adsorption behavior of the sediment sample, the relative errors of these three models were quite close. The results illustrate that SCMs can be used to successfully model natural materials.

\section{Introduction}

The behavior, transport, and ultimate fate of heavy metals in aquatic environment depend largely on their sorption reactions with sediment particles (1-4). Thus, it is very important to investigatesuch reactions. Differentempirical approaches, in particular the measurement of adsorption isotherms and the corresponding partitioning parameters, have commonly been used in the studies of the adsorption behavior of natural sediments or soils (5-10). However, limitations of these empirical ways have been observed ( 1 , 11-13). Extensive studies have been made on surface complexation models (SCMs) to describe the adsorption of heavy metals on pure mineral surfaces, especially on pure hydrous oxide solid surfaces; the results are quite promising (14-23). It has also been hoped that SCM s can be used with natural materials, but unfortunately, there have been very few studies that apply SCMs to natural materials and to sediments in particular.

Mouvet and Bourg (24) were the first to use the chemical equilibrium models to quantitatively describetheadsorption data of metals to river sediment. They reported that the adsorption constants of the metals are directly proportional to their first hydrolysis constants. They concluded that to

* Corresponding author present address: Department of Environmental Engineering, University of Tsinghua, Beijing 100084, People's Republic of China. Phone: 86-010-62785684; fax: 86-01062785687; e-mail: shc-den@mail.tsinghua.edu.cn. a certain degree the chemical equilibrium program can be used to predict the speciation of $\mathrm{Cu}, \mathrm{Ni}, \mathrm{Pb}$, and $\mathrm{Zn}$ in a river. Fu and Allen (25) studied the $\mathrm{Cd}$ adsorption on an oxic sediment sample by carrying out both acid-base titration experiments and Cd adsorption experiments with the sediment sample. They used a multisite binding model that contained the effect of $\mathrm{pH}$ by considering the titration data against their adsorption data. The results derived from the model were close to that from the experiment. They suggested that the adsorption behavior of natural sediment can be modeled via one or two surface reactions. Charlet (26) and Osaki et al. $(27,28)$ used the concept of triple layer SCM s and constant capacitance SCMs to study the behavior of metal adsorption on oxic sediment. Wang (29) tried successfully to apply the diffuse layer SCMs to describe his metal adsorption data. Some researchers have also used SCMs in the area of soil science. Goldberg $(11,12)$ was the first person to extend the use of CCM to describeo-phosphate adsorption by noncalcareous mineral soils. Goldberg believed that CCM did the best job of describing o-phosphate adsorption by noncalcareous soils, including the effect of $\mathrm{pH}$. UsingSCMsto describetheadsorption behavior of pure clay minerals has been reported (30-32). Although these studies have employed SCMs to describe adsorption, SCMs have not been widely used with natural materials because of insufficient or missing data, particularly a data base of model constants and pertinent information regarding surface properties of natural sediment (21-29). Obviously, more work is needed in this field.

Theoretically, it is not quite clear yet which of the three frequently used surface complexation models (CCM, DLM, and TLM) is best in reflecting the chemical principles in describing the adsorption processes in a natural system (20, 33-36). Dzombak and Morel (20) carefully evaluated the distinguishing aspects of these different versions of surface complexation models. It was shown that all three SCM scan simulate the experimental data of cation adsorption on pure metal hydroxide solid very well $(1,35-37)$. However, no comparison of the performance of these three models in describing adsorption on natural sediments has been reported.

The purpose of this study was to use the SCM approach to describe the adsorption of heavy metals to natural river sediments. Generally speaking, SCM s can be applied in two different ways to composite materials. The first is to treat the composite material as an integrated whole with adsorption described as complexation with average surface functional groups. Thesecond isto consider themain composites that are supposed to dominate adsorptive interactions. Initially the first approach was chosen for this work. A river sediment samplethat was collected from LeAn River in Jiangxi Province, China, was used. Potentiometric titration and adsorption experiments were conducted to provide the data set to calibrate the model parameters. The effectiveness of the three SCMs in interpreting the experimental data were tested and compared.

\section{Materials and Methods}

Samples. The sediment sample was free of pollution as demonstrated by previous desorption tests (38). Thesample was air-dried, and particles larger than 200 mesh were removed by a nylon sieve. An X-ray fluorescence spectrometer (3080E3, RIGAKU Industrial Co., Japan) was used to analyze its mineral composition. An X-ray diffraction spectrometer (HZG-4x, DanDong Analytical Equipment Co., China) was used to analyze the clay composition. The $\mathrm{N}_{2} /$ 
TABLE 1. Element Content of Sample As Measured by X-ray Fluorescence Spectrometry

\begin{tabular}{cccccccccccc} 
element & $\mathrm{Ca}(\%)$ & $\mathrm{Mg}(\%)$ & $\mathrm{Na}(\%)$ & $\mathrm{K}(\%)$ & $\mathrm{Si}(\%)$ & $\mathrm{Fe}(\%)$ & $\mathrm{Al}(\%)$ & $\mathrm{Mn}(\mathrm{ppm})$ & $\mathrm{Cu}(\mathrm{ppm})$ & $\mathrm{Pb}(\mathrm{ppm})$ & $\mathrm{Zn}(\mathrm{ppm})$ \\
amount & 0.26 & 0.58 & 0.34 & 2.02 & 29.53 & 4.14 & 8.68 & 1207 & 56 & 36.2 & 156 \\
\hline
\end{tabular}

TABLE 2. Intrinsic Surface Constants of Sediment Sample

\begin{tabular}{|c|c|c|c|c|c|c|c|c|c|c|}
\hline & \multirow{3}{*}{$\begin{array}{l}\text { solution methods } \\
\text { model type } \\
\text { ionic strength }\end{array}$} & \multirow{2}{*}{\multicolumn{3}{|c|}{$\begin{array}{l}\text { graphic methods } \\
\text { CCM }\end{array}$}} & \multicolumn{6}{|c|}{ FITEQL 2.0 optimization } \\
\hline & & & & & \multirow{2}{*}{ TLM } & \multicolumn{3}{|c|}{ CCM } & \multirow{2}{*}{$\begin{array}{l}\text { DLM } \\
0.01\end{array}$} & \multirow{2}{*}{$\begin{array}{l}\text { TLM } \\
0.01\end{array}$} \\
\hline & & 0.1 & 0.01 & 0.001 & & 0.1 & 0.01 & 0.001 & & \\
\hline intrinsic constants & $\begin{array}{l}\mathrm{p} K_{\mathrm{a} 1}{ }^{\text {int }} \\
\mathrm{p} K_{\mathrm{a} 2}{ }^{\text {int }} \\
\mathrm{p} K_{\mathrm{Na}^{+}}{ }^{\text {int }} \\
\mathrm{p} K_{\mathrm{NO}_{3}}{ }^{\text {int }}\end{array}$ & $\begin{array}{l}3.31 \\
4.27\end{array}$ & $\begin{array}{l}2.97 \\
4.80\end{array}$ & $\begin{array}{l}2.80 \\
5.07\end{array}$ & $\begin{array}{l}2.80 \\
5.37 \\
3.27 \\
4.06\end{array}$ & $\begin{array}{l}3.17 \\
4.25\end{array}$ & $\begin{array}{l}3.01 \\
4.93\end{array}$ & $\begin{array}{l}2.73 \\
5.35\end{array}$ & $\begin{array}{l}1.49 \\
4.73\end{array}$ & $\begin{array}{l}2.73 \\
5.35 \\
4.76 \\
3.00\end{array}$ \\
\hline error analysis & $\begin{array}{l}\sigma_{\mathrm{p} K_{\mathrm{a} 1}{ }^{\text {int }}} \\
\sigma_{\mathrm{p} K_{\mathrm{a} 2}{ }^{\text {int }}}\end{array}$ & & & & & $\begin{array}{l}0.208 \\
0.879\end{array}$ & $\begin{array}{l}0.231 \\
0.066\end{array}$ & $\begin{array}{l}0.310 \\
0.057\end{array}$ & $\begin{array}{l}7.274 \\
0.039\end{array}$ & \\
\hline & $\sigma_{\mathrm{p} K_{\mathrm{Na}} t^{\text {int }}}$ & & & & & & & & & 0.293 \\
\hline capacity & $\begin{array}{l}\sigma_{\mathrm{p}_{\mathrm{NO}_{3}}{ }^{-i n t}} \\
V_{\mathrm{Y}} \\
C_{1}\left(\mathrm{~F} / \mathrm{m}^{2}\right) \\
C_{2}\left(\mathrm{~F} / \mathrm{m}^{2}\right)\end{array}$ & & & & & $\begin{array}{l}1.32 \\
1.76\end{array}$ & $\begin{array}{l}0.935 \\
1.66\end{array}$ & $\begin{array}{l}0.924 \\
1.45\end{array}$ & 5.004 & $\begin{array}{l}0.054 \\
2.641 \\
1.60 \\
0.20\end{array}$ \\
\hline
\end{tabular}

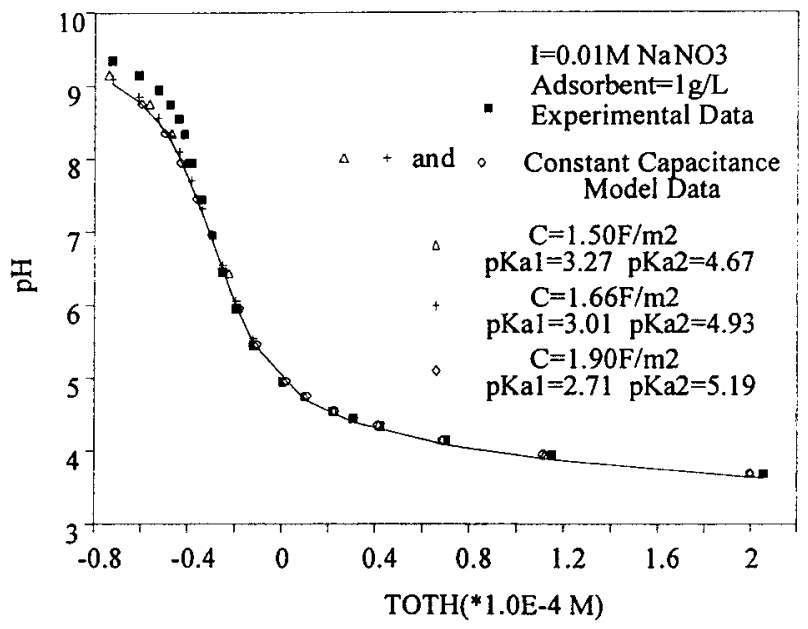

FIGURE 1. Fitting titration curves by the constant capacitance model. Each fitting curve is calculated based on the corresponding $\mathrm{p} K$ and $C$ for that of ionic strength. The sample is from the LeAn River.

BET method (ASAP-2000, Micromeritics) was used to determinethe specific area of the sample. Theorganic content of the sample was analyzed by using the standard $\mathrm{K}_{2} \mathrm{Cr}_{2} \mathrm{O}_{7}$ oxidation method (37). The sediment stock suspension was made by adding $10 \mathrm{~g}$ of sediment to $1 \mathrm{~L}$ of triple distilled water and waskept in a refrigerator for at least 2 weeks before the titration and adsorption experiments started.

Potentiometric Titration. The potentiometric titration experiment was done in a $100-\mathrm{mL}$ Erlenmeyer flask. A 10$\mathrm{mL}$ stock sediment suspension was added to the flask to give a sediment concentration of $1 \mathrm{~g} / \mathrm{L}$. $\mathrm{NaNO}_{3}$ was added to maketheionic strength of the suspension $0.1,0.01$, and 0.001 $\mathrm{mol} / \mathrm{L}$, respectively. Triple distilled water was added to give a final volume of the suspension of $100 \mathrm{~mL}$. $\mathrm{HNO}_{3}$ was added to givea suspension $\mathrm{pH}$ value of less than 3 . The samplewas stirred for $1 \mathrm{~h}$ with a magnetic stirrer and was equilibrated for 30 min to get a stable $\mathrm{pH}$. Thereafter, $\mathrm{NaOH}$ was microadded until the suspension $\mathrm{pH}$ was greater than 10; this was monitored using a Metrohm 682 automatic titroprocessor. During the titration process, the suspension was continually bubbled with $\mathrm{N}_{2}$ to exclude the effect of $\mathrm{CO}_{2}$, and the temperature was held at $25^{\circ} \mathrm{C}$. The reference blank was prepared in the same manner as the sample except that no $\mathrm{HNO}_{3}$ was added and only the supernatant of the suspension

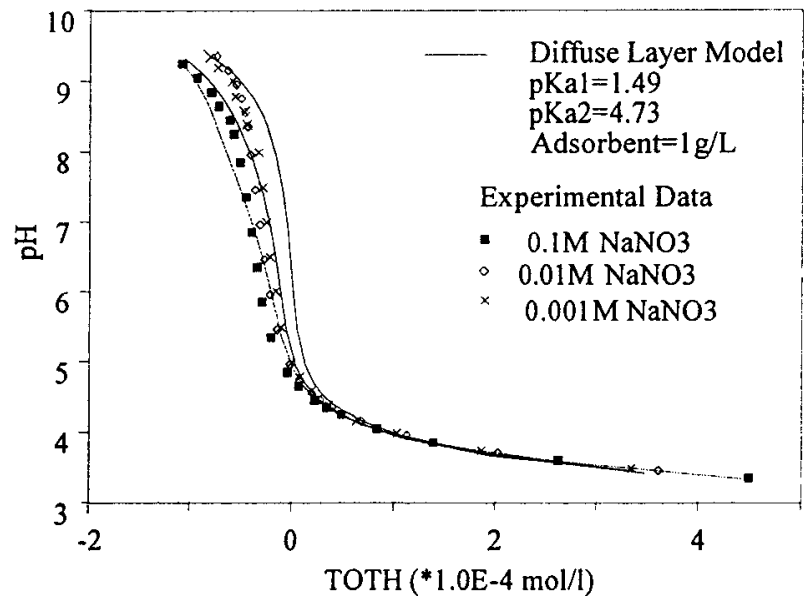

FIGURE 2. Fitting titration curves by the diffuse layer model. Parameters are derived from the data of $0.01 \mathrm{~mol} / \mathrm{L}$ ionic strength. The sample is from the LeAn River.

was titrated. The surface charges of the sample at different $\mathrm{pH}$ and ionic strengths were calculated based on eq 1 . The data sets of $\mathrm{pH}$ valueversus surface charge $\left(\sigma_{\mathrm{H}}\right)$ were obtained and used to derive surface site density, $\mathrm{pH}_{\mathrm{pzc}}$, and also the surface acidic constants:

$\begin{aligned} \sigma_{\mathrm{H}}=\left[\left(\mathrm{V}_{\mathrm{HCl}} \mathrm{N}_{\mathrm{HCl}}-\right.\right. & \left.\mathrm{V}_{\mathrm{NaOH}} \mathrm{N}_{\mathrm{NaOH}}\right)_{\mathrm{Sample}}- \\ & \left.\left(\mathrm{V}_{\mathrm{HCl}} \mathrm{N}_{\mathrm{HCl}}-\mathrm{V}_{\mathrm{NaOH}} \mathrm{N}_{\mathrm{NaOH}}\right)_{\mathrm{Blank}}\right] / \mathrm{W}\end{aligned}$

where $\sigma_{\mathrm{H}}$ is the surface charge $(\mathrm{mol} / \mathrm{g}) ; \mathrm{V}$ is the volume of acid or base added $(\mathrm{mL}) ; \mathrm{N}$ is the concentration of acid or base added ( $\mathrm{mmol} / \mathrm{L}) ; \mathrm{W}$ is the amount of sediment sample (g).

Adsorption. Cu and $\mathrm{Cd}$ were selected as the absorbates. The adsorption experiments were conducted under two different conditions. One employed a constant $\mathrm{pH}$ with a range of metal concentrations from which the adsorption isotherms were obtained. The other one used an array of $\mathrm{pH}$ value with several fixed metal concentrationsfrom which the adsorption edge curves were obtained. The experiments were carried out in a series of $100-\mathrm{mL}$ plastic bottles. Each bottle had $10 \mathrm{~mL}$ of sediment stock suspension added to make the solid concentration $1 \mathrm{mg} / \mathrm{L}$. The $\mathrm{pH}$ of the suspension was adjusted by adding $\mathrm{HNO}_{3}$ or $\mathrm{NaOH}$. The suspension ionic strength was adjusted by adding $\mathrm{NaNO}_{3}$ to 


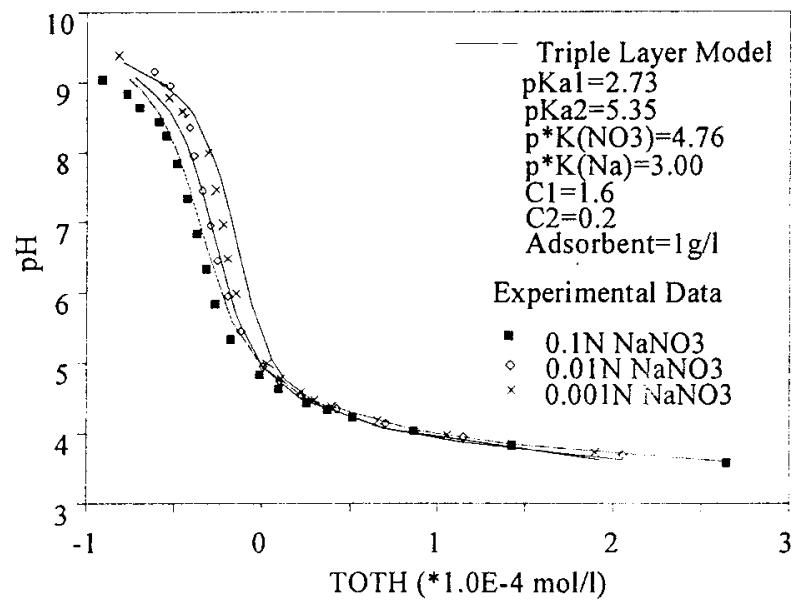

FIGURE 3. Fitting titration curves by the triple layer model. Parameters are derived from the data of $0.01 \mathrm{~mol} / \mathrm{L}$ ionic strength. The sample is from the LeAn River.

$0.01 \mathrm{~mol} / \mathrm{L}$ to make it close to the ionic strength of natural waters. The $\mathrm{Cu}$ or $\mathrm{Cd}$ concentration of the suspension was adjusted to the designed values using standard $\mathrm{Cu}$ or $\mathrm{Cd}$ solutions. The samples were then shaken for $3 \mathrm{~h}$ in a reciprocating shaker and were equilibrated for $24 \mathrm{~h}$ at $25^{\circ} \mathrm{C}$. Part of the supernatant was used for $\mathrm{pH}$ measurement, and part of the supernatant was filtrated through a $0.45-\mu \mathrm{m}$ membrane for metal concentration measurement using a PE-3100 atomic absorption spectrometer. The data of the adsorption isotherms were used to calibrate the adsorption parameters for the models by using the FITEQL 2.0 program (40). The data of the $\mathrm{pH}$ edges were used to verify the performance of the established models.

Parameter Estimation Methods. There are two important steps when using a surface complexation model. One is to properly choose the models that relate to the assumptions of the electrical doublelayer and thecalculation method. The other is to determine the model parameters correctly. In this work, three frequently used surface complexation models are considered. Themass law equation and thestatic electronic expressions of these three models can be found in the literature (14-20). Both the graphical extrapolation method, which has been illustrated clearly in literature (1420 ), and the nonlinear least squares optimization procedure with the FITEQL 2.0 program were employed to analyze the data. They are referred to as the graphical method and the computer method, respectively, in the following discussion.

\section{Results and Discussion}

Sample Characteristics. The results of X-ray fluorescence analysis are listed in Table 1 . The clay $(<2 \mathrm{~mm})$ content of the sediment sample is mainly composed of $71 \%$ illite, $15 \%$ kaolinite, and $14 \%$ chlorite. Particles smaller than $2 \mathrm{~mm}$ comprised $19 \%$ of the total particle size spectrum. The specific area of the samplewas $13.3 \mathrm{~m}^{2} / \mathrm{g}$. The total number of surface sites $\left(\mathrm{N}_{\mathrm{s}}\right)$ is obtained by extrapolating a plot of the distribution coefficient $\left(\mathrm{K}_{\mathrm{d}}=\sigma_{\mathrm{H}} /\left[\mathrm{H}^{+}\right]\right)$vs $\sigma_{\mathrm{H}}(26)$. Three $\mathrm{N}_{\mathrm{s}}$ values were obtained from three sets of titration data at different ionic strengths. The average of the three values was $7.9 \times 10^{-5}$ mol sites per gram. The $\mathrm{pH}_{\mathrm{pzc}}$ of 4.2 was obtained from the crossover point of the threetitration curves at different ionic strengths.

Surface Acidic Properties and Constants. The titration data were arranged in the format of data input for FITEQL, which is total $\mathrm{H}^{+}(\mathrm{TOTH})$ concentration vs $\mathrm{pH}$. TOTH was calculated from the titration data by using the BASIC computer program given by Dzombak and Morel (20). The data sets of $\mathrm{pH}$ vs TOTH for different ionic strengths are
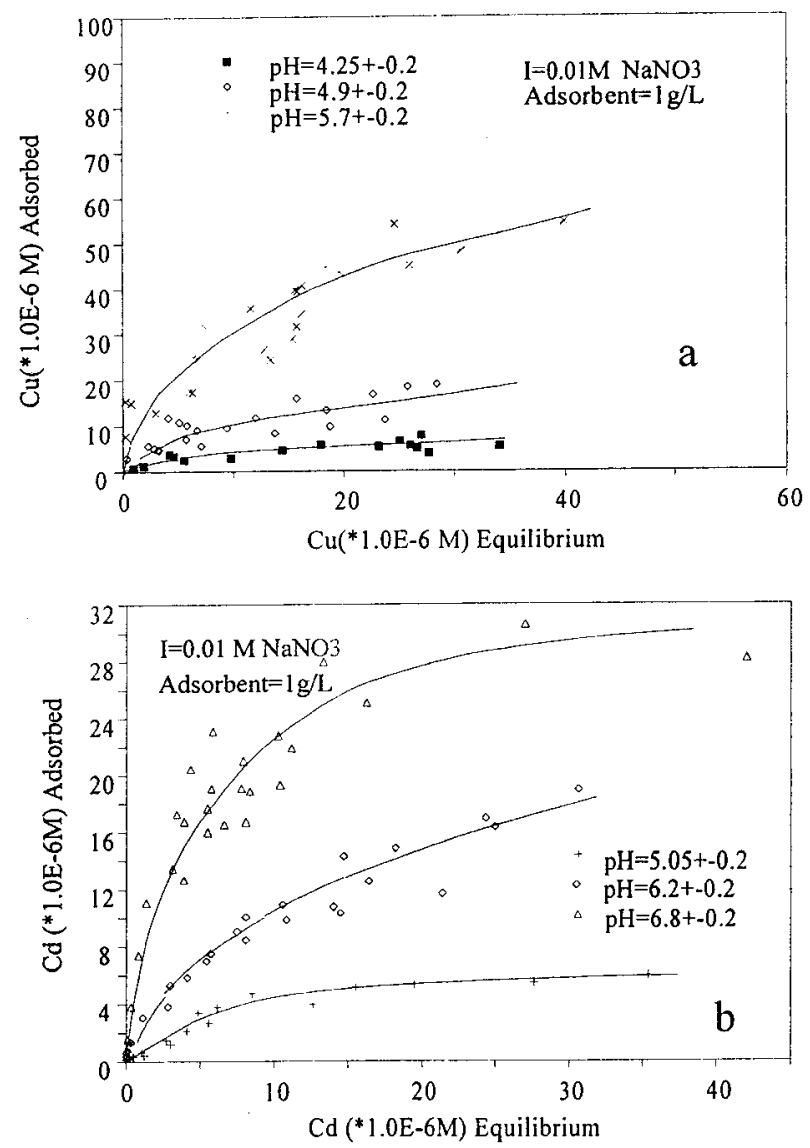

FIGURE 4. Adsorption isotherms of the sediment sample for $\mathrm{Cu}$ (a) and $C d(b)$. The sample is from the LeAn River.

TABLE 3. Intrinsic Surface Complexation Constants of the Sediment Sample

\begin{tabular}{|c|c|c|c|c|}
\hline adsorbate & constants & CCM & DLM & TLM \\
\hline $\mathrm{Cu}(\mathrm{II})$ & $\begin{array}{l}\log K_{\mathrm{M}^{2+}} \text { int } \\
\log K_{\mathrm{MOH}^{+}}{ }^{i n t}\end{array}$ & -0.766 & -1.247 & $\begin{array}{r}0.058 \\
-4.599\end{array}$ \\
\hline $\mathrm{Cd}(\mathrm{II})$ & $\begin{array}{l}\log K_{\mathrm{M}^{2+}}{ }^{i n t} \\
\log K_{\mathrm{MOH}^{+}} \text {int } \\
C_{1}\left(\mathrm{~F} / \mathrm{m}^{2}\right) \\
C_{2}\left(\mathrm{~F} / \mathrm{m}^{2}\right)\end{array}$ & $\begin{array}{c}-1.960 \\
1.66\end{array}$ & -2.585 & $\begin{array}{l}-0.455 \\
-6.385 \\
1.60 \\
0.20\end{array}$ \\
\hline
\end{tabular}

drawn point by point in Figures 1-3. It can been seen that the sample is negatively charged over a large $\mathrm{pH}$ range.

As mentioned above, the sediment is considered as an integrated whole with an average surface functional group (expressed as $\mathrm{SOH}$ ). The surface protonation and deprotonation of the sediment are expressed as eqs 2 and 3.

$$
\begin{aligned}
& \mathrm{SOH}_{2}^{+}=\mathrm{SOH}+\mathrm{H}^{+} \quad \mathrm{K}_{\mathrm{al}}{ }^{\text {int }} \\
& \mathrm{SOH}=\mathrm{SO}^{-}+\mathrm{H}^{+} \quad \mathrm{K}_{\mathrm{a} 2}{ }^{\text {int }}
\end{aligned}
$$

For different surface complexation models, the considerations in calculating acidic constants are different, and this has been expounded clearly by a number of researchers $(20,24,25,29,30)$. These calculations were tried for the natural sediment sample. It is obvious that the derived parameters are very much model specific; in other words, different models yield different parameter sets of $\mathrm{pK}$ and/ or capacitance, $\mathrm{C}$.

Constant Capacitance Model. Theoretically, only one plane in the intersurface is considered in this model. All the specific adsorbed ions are assigned into the surface plane, and they contribute to $\sigma_{0}$ and experience the potential $\psi_{0}$. 
The electrical double layers are Helmholtz type. It is like a capacitor with a pair of plates in parallel and with a fixed electrical capacitance (C) for each of the corresponding combinations of temperature, ionic strength, and the electrolyte property $(1,24,25,29,30)$. The model has three specific parameters $\left(\mathrm{C}, \mathrm{pK}_{\mathrm{a} 1}{ }^{\mathrm{int}}\right.$, and $\left.\mathrm{pK}_{\mathrm{a} 2}{ }^{\mathrm{int}}\right)$. In this study, both the graphical method and the computer method are employed to evaluate the surface characteristic constants. Three sets of parameters including an electric capacity (C) and two intrinsic acidity constants ( $\mathrm{pK}_{\mathrm{a1}}{ }^{\text {int }}$ and $\mathrm{pK}_{\mathrm{a} 2}{ }^{\text {int }}$ ) are obtained respectively from the three data sets of different ionic strengths. These two methods produce very similar results as shown in Table2. The capacitance value required to do FITEQL 2.0 optimization was taken from the graphical method.

The derived parameters are incorporated into the model to reproduce the titration curves as depicted in Figure 1 . It is obvious that the results calculated by the model matched well with the experimental results.

Diffuse Layer Model. This model assigns two planes in the interfacial region: a surface plane for adsorption of $\mathrm{H}^{+}$, $\mathrm{OH}^{-}$, and all specifically adsorbed species, and a diffuselayer plane representing the closest distance of approach for all counterions. The distribution of ions, charge, and potential in the diffuse layer is described by the Poisson-Boltzmann equation. The overall relationship between surface charge and the potential is given by the Gouy-Chapman equation $(1,29,30)$. As indicated by Dzombak and Morel (20), DLM uses only two constants ( $\mathrm{pK}_{\mathrm{al}}{ }^{\mathrm{int}}$ and $\mathrm{pK}_{\mathrm{a} 2}{ }^{\mathrm{int}}$ ) to express the surface characteristics at variable ionic strengths. In this work, the acidity constants are extracted by using FITEQL 2.0 with the titration data at $0.01 \mathrm{~mol} / \mathrm{L}$ ionic strength. The parameters are listed in Table 2 . In turn, the parameters are used in the model to reproduce a titration curve for each of thethree data sets at the different ionic strengths. The results are shown in Figure 2. It can be seen that the model calculation results match with the experimental data points very well. This confirms that in DLM the influences of ionic strength areal ready imbedded into themodel itself; therefore, the model applies in different solution conditions.

TripleLayer Model. In thismodel, there arethreeplanes in the interfacial region: a surface plane for adsorption of $\mathrm{H}^{+}, \mathrm{OH}^{-}$, and strongly adsorbed ions; a near-surface plane (the $\beta$-plane) for weakly adsorbed ions; and a diffuse layer plane, representing the closest distance of approach of dissociated charge. Onedistinctive advantage of TLM is that it takes the influence of electrolyte ions into account in the calculations so that the model parameters such as $\mathrm{pK}_{\mathrm{a} 1}{ }^{\mathrm{int}}$, $\mathrm{pK}_{\mathrm{a} 2}{ }^{\mathrm{int}}, \mathrm{pK}_{\mathrm{NO}_{3}}{ }^{-{ }^{-i n t}}$ and $\mathrm{pK}_{\mathrm{Na}^{+}}{ }^{+i n t}$ are independent of electrolyte concentration. As a result, the TLM can interpret data over a wide range of ionic strengths. Sixparameters $\left(\mathrm{C}_{1}, \mathrm{C}_{2}, \mathrm{pK}_{\mathrm{al}}{ }^{\mathrm{int}}\right.$, $\mathrm{pK}_{\mathrm{a} 2}{ }^{\text {int }}, \mathrm{pK}_{\mathrm{NO}_{3}}{ }^{\text {int }}$, and $\mathrm{pK}_{\mathrm{Na}^{+}}{ }^{\text {int }}$ ) are required for this model. In this work, $\mathrm{pK}_{\mathrm{al}}{ }^{\text {int }}$ and $\mathrm{pK}_{\mathrm{a} 2}{ }^{\text {int }}$ are evaluated by the graphical method, whereas $\mathrm{pK}_{\mathrm{NO}_{3}}{ }^{-}$and $\mathrm{pK}_{\mathrm{Na}^{+}}$are evaluated with both the graphical and the computer methods for the $0.01 \mathrm{~mol} / \mathrm{L}$ ionic strength titration data. Simultaneous optimization of the values of $\mathrm{pK}_{\mathrm{al}}{ }^{\mathrm{int}}, \mathrm{pK}_{\mathrm{a} 2}{ }^{\mathrm{int}}, \mathrm{pK}_{\mathrm{Na}^{+}}{ }^{\mathrm{int}}$, and $\mathrm{pK}_{\mathrm{NO}_{3}}{ }^{\text {int }}$ by using FITEQL 2.0 were tried but failed. $\mathrm{pK}_{\mathrm{NO}_{3}}{ }^{-i n t}$ and $\mathrm{pK}_{\mathrm{Na}^{+}}{ }^{\mathrm{int}}$ were predicted by using FITEQL 2.0 while treating the $\mathrm{pK}_{\mathrm{al}}{ }^{\text {int }}$ and the $\mathrm{KK}_{\mathrm{a} 2}{ }^{\text {int }}$ values from the graphical method. Theparameters derived from the $0.01 \mathrm{~mol} / \mathrm{L}$ ionic strength experimental data were then put back into the TLM to reproduce the titration curves. The results are very close to titration experimental data of all three different ionic strengths in Figure 3. This proves the effectiveness of the model in interpreting the data over a wide range of ionic strengths. However, since this model requires that the values of more parameters be determined than is required for the other models, application is more difficult.

Adsorption Properties and Constants. Langmuir adsorption isotherms for the adsorption of $\mathrm{Cu}$ and $\mathrm{Cd}$ on the sediment at different $\mathrm{pH}$ values are shown in Figure 4. For both $\mathrm{Cu}$ and $\mathrm{Cd}$, there is a maximum adsorption at each $\mathrm{pH}$. The adsorption increases for $\mathrm{Cu}$ when the $\mathrm{pH}$ increases from 4.25 to 5.7 and for $\mathrm{Cd}$ when the $\mathrm{pH}$ increases from 5.05 to 6.8.

The adsorption of heavy metals $\left(\mathrm{M}^{2+}\right)$ on the sediment surface is expressed in eqs 4 and 5 . Based on the theoretical hypotheses of CCM, DLM, and TLM $(1,20)$, only eq 4 is used in the CCM and DLM calculations, while both eqs 4 and 5 are used in the TLM calculation.

$$
\begin{gathered}
\mathrm{SOH}+\mathrm{M}_{\mathrm{S}}^{2+}=\mathrm{SO}^{-}-\mathrm{M}^{2+}+\mathrm{HS}^{+} \\
\mathrm{SOH}+\mathrm{M}_{\mathrm{S}}^{2+}+\mathrm{H}_{2} \mathrm{O}=\mathrm{SO}^{-}-\mathrm{MOH}^{+}+2 \mathrm{H}_{\mathrm{S}}^{+}
\end{gathered}
$$

The data of the isotherms together with the intrinsic surface constants listed in Table 1 are used to determine the intrinsic adsorption constants by using FITEQL 2.0 for the three surface complexation models. For each model, one set of constants is obtained for each isotherm at a fixed $\mathrm{pH}$. Three adsorption isotherms are obtained. Thus, three sets of constants are derived for each of the models. The values of the constants listed in Table 3 are the average of the three related numbers calculated by using Dzombak and Morel's method (20). Comparing the intrinsic complexation constants of $\mathrm{Cu}$ and $\mathrm{Cd}$ in Table 2, we find that $\mathrm{Cu}$ has a higher affinity with this river sediment than does $\mathrm{Cd}$.

Performance of the Models in Data Interpreting. The surface complexation models, which have been viewed as mechanistic models $(1,20)$, should be effectively used to describe the adsorption behavior in the different conditions from those used for parameter extraction. As a verification step for the models, the parameters derived from the adsorption isotherms obtained at several fixed $\mathrm{pH}$ values were incorporated into the three surface complexation models to reproduce the $\mathrm{pH}$ edge curves, which are over a
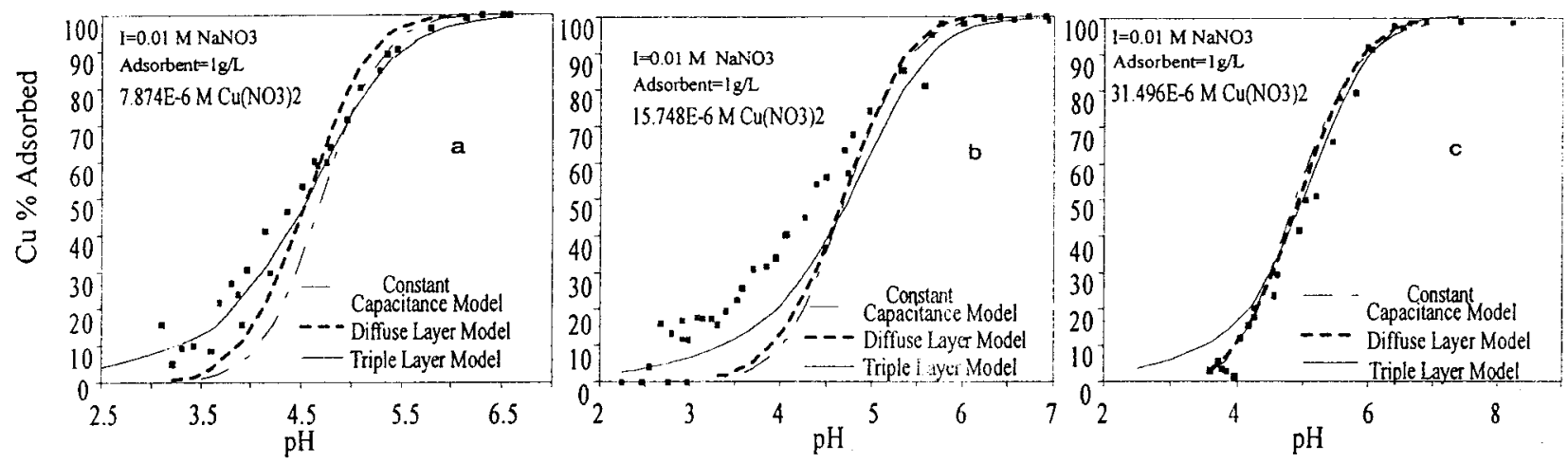

FIGURE 5. Fitting curves for the adsorption edges of $\mathrm{Cu}$ with the three surface complexation models for LeAn River sediment sample. 

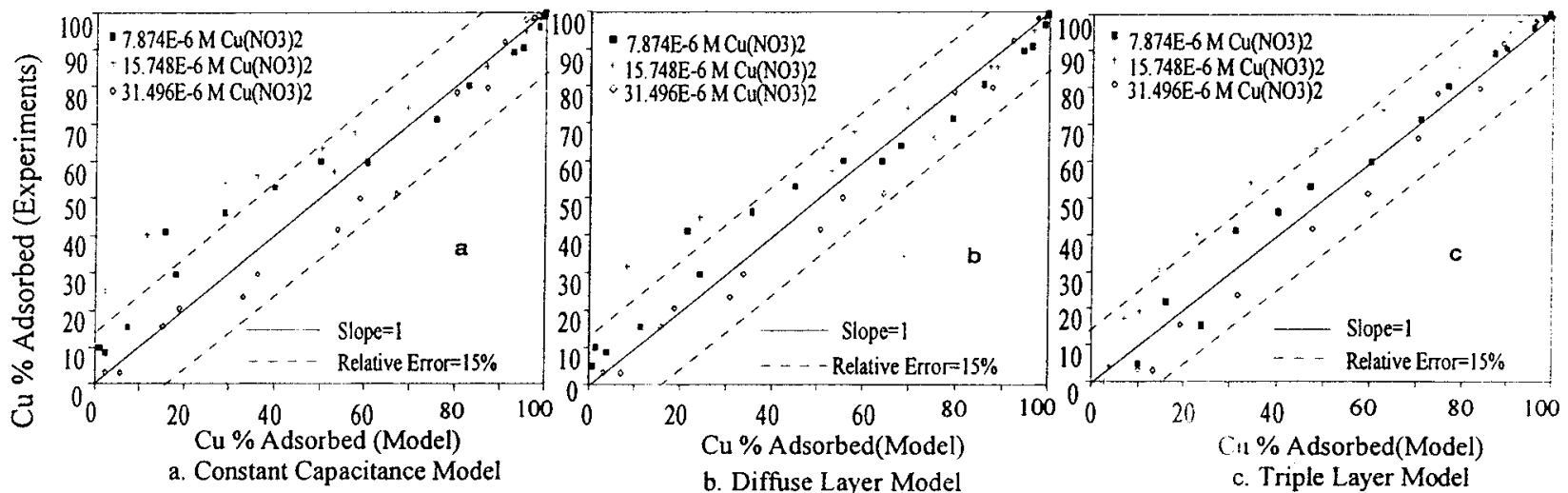

FIGURE 6. Relative error analysis for the fits of $\mathrm{Cu}$ adsorption pH edges.
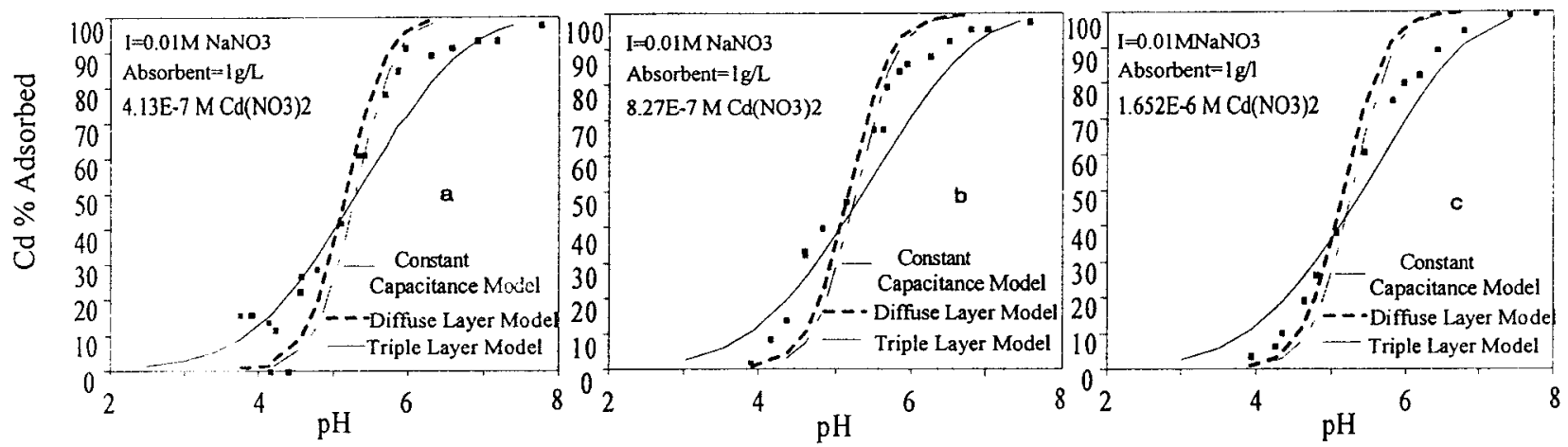

FIGURE 7. Fitting curves for the adsorption edges of $\mathrm{Cd}$ with the three surface complexation models for LeAn River sediment sample.

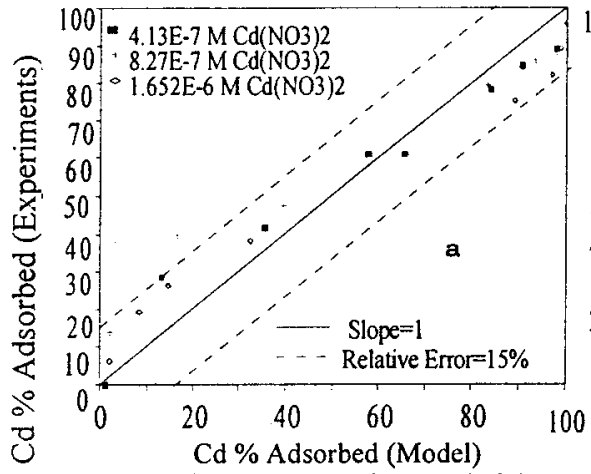

a. Constant Capacitance Model

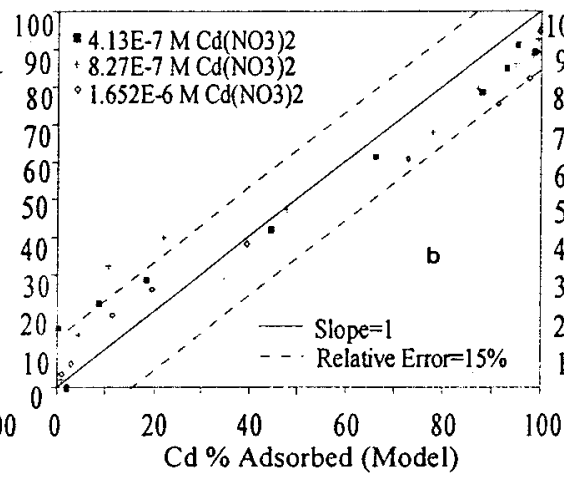

b. Diffuse Layer Model

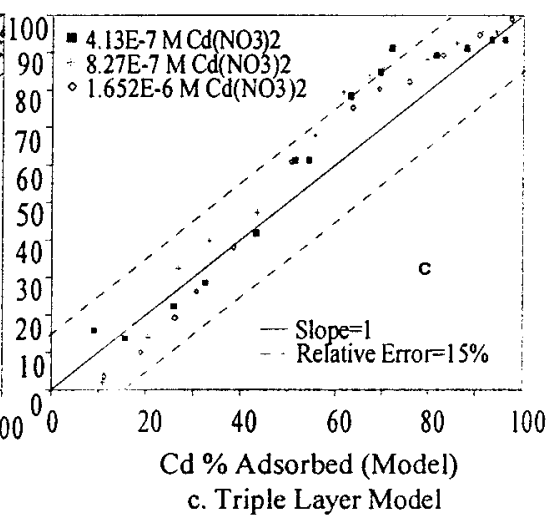

FIGURE 8. Relative error analysis for the fits of $\mathrm{Cd}$ adsorption pH edges.

wide range of $\mathrm{pH}$, by using the MICROQL program (41). Figures 5 and 7 show the experimental data and the model fitting curves for $\mathrm{Cu}$ and $\mathrm{Cd}$ adsorption $\mathrm{pH}$ edges with different $\mathrm{Cu}$ and $\mathrm{Cd}$ concentrations. Figures 6 and 8 show the relative errors of each of the fitting results for all three models.

Model calculation results as well as the experimental results shown in Figures 5-8 indicate that the adsorption of the metals on the river sediment sample is strongly $\mathrm{pH}$ dependent. Alargepercentage of theadsorption of themetals occurs in a narrow range of $\mathrm{pH}$. With the increase of the total metal concentration, the $\mathrm{pH}$ adsorption edge shifts to a high $\mathrm{pH}$ range, which is equivalent to the reduction of the adsorption affinity.

From the results shown in Figures $5-8$, it has been concluded that all three models can interpret the experimental data of the $\mathrm{pH}$ adsorption edges for $\mathrm{Cu}$ and $\mathrm{Cd}$ very well, which means that all three surface complexation models apply very well in describing the adsorption behavior of the natural sediment. In this case, the relative errors are within
$15 \%$. Although this does not tell which model is correct in a mechanistic sense, it indicates that the SCMs can be used to describe adsorption to natural sediments.

\section{Acknowledgments}

This research was sponsored by the Chinese Natural Science Foundation.

\section{Literature Cited}

(1) Davis, J. A.; Kent, D. B. In Mineral-water InterfaceGeochemistry; Hochella, M. F., Jr., White, A. F., Eds.; Mineralogical Society of America: Madison, WI, 1990; pp 177-259.

(2) Luoma, S. N.; Davis, J. A. Mar. Chem. 1983, 12, 159.

(3) Forstner, U. Contaminated Sediments; Springer-Verlag: Berlin, Heidelberg, 1989.

(4) Tessier, A.; Carignan, R.; Dubreuil, B.; Rapin, F. Geochim. Cosmochim. Acta 1989, 53, 1511.

(5) Bolt, G. H.; Van Riemsdijk, W. H. In Aquatic Surface Chemistry; Stumm, W., Eds.; Wiley-Interscience: New York, 1987; 145164. 
(6) Sigg, L. In Aquatic SurfaceChemistry; Stumm, W., Eds.; A WileyInterscience: New York, 1987; pp 319-349.

(7) Allen, H. E.; Chen, Y. T.; Li, Y. M.; Huang, C. P.; Sanders, P. F. Environ. Sci. Technol. 1995, 29, 1887.

(8) Kinniburg, D. G. Environ. Sci. Technol. 1986, 20, 895.

(9) Belzile, N.; Tessier, A. Geochim. Cosmochim. Acta 1990, 54, 103.

(10) Ramamoorthy, S.; Rust, B. R. Environ. Geol. 1978, 2 (3), 165.

(11) Goldberg, S.; Sposito, G. Soil Sci. Soc. Am. J. 1984, 48, 772.

(12) Goldberg, S.; Sposito, G. Soil Sci. Soc. Am. J. 1984, 48, 779

(13) Honeyman, B. D.; Leckie, J. O. In Geochemical Processat Mineral Surface; Davis, J. A., Hay, K. F., Ed.; American Chemical Society: Washington, DC, 1986.

(14) Stumm, W.; Huang, C. P.; Jenkins S. R. Croat. Chem. Acta 1970, $42,223$.

(15) Hohl, H.; Stumm, W. J. Colloid Interface Sci. 1976, 55, 281

(16) Huang, C. P.; Elloitt, H. A. J. Water Pollut. Control Fed. 1977, $5,745$.

(17) Davis, J. A.; James, R. O.; Leckie, J. O. J. Colloid Interface Sci. 1978, 63, 480.

(18) Davis, J. A.; Leckie, J. O. J Colloid Interface Sci. 1978, 67, 90.

(19) Hayes, K. F.; Leckie, J. O. J. Colloid InterfaceSci. 1991, 142, 448.

(20) Dzombak, D. A.; Morel, F. M. M. Surface Complexation Modeling: Hydrous Ferric Oxide; John Wiley: New York, 1990.

(21) Katz, L. Y.; Hayes, K. F. J. Colloid Interface Sci. 1995, 170, 477.

(22) Katz, L. Y.; Hayes, K. F. J. Colloid Interface Sci. 1995, 170, 491.

(23) Nowack, B.; Lutzenkirchen, J.; Behra, P.; Sigg., L. Environ. Sci. Technol. 1996, 30, 2397.

(24) Mouvet, C.; Bourg, A. C. M. Water Res 1983, 17, 641.

(25) Fu, G. M.; Allen, H. E. Water Res. 1992, 26, 225

(26) Charlet, L. Ph.D. Thesis, University of California, 1986.

(27) Osaki, S.; Miyoshi, T.; Sugihara, S.; Takashima, S. Sci. Total Environ. 1990, 99, 105.

(28) Osaki, S.; Miyoshi, T.; Sugihara, S.; Takashima, S. Sci. Total Environ. 1990, 99, 115.
(29) Wang, F. Y. Ph.D. Dissertation, Peking University, China, 1995.

(30) Schindler, P. W.; Fürst, B.; Dich, R.; Wolf, P.U.J. Colloid Interface Sci. 1976, 55, 469

(31) Schindler, P. W.; Liechti, P.; Westall, J. C. Neth. J. Agric. Sci. 1987, 35, 219.

(32) Zachara, J. M.; Smith, S. C. Soil Sci. Soc. Am. J. 1994, 58, 762.

(33) Tang, H. X. Adv. Environ. Sci. 1993, 1 (1), 25.

(34) Tang, H. X. Adv. Environ. Sci. 1993, 1 (2), 1.

(35) Westall, J. In Geochemical Process at Mineral Surfaces; Davis, J. A., Hays, K. F., Eds.; American Chemical Society: Washington, DC, 1986; pp 55-77.

(36) Westall J. In Aquatic Surface Chemistry; Stumm, W., Ed.; A Wiley-Interscience: New York, 1987; pp 3-32.

(37) Westall, J.; Hohl, H. Adv. Colloid Interface Sci. 1980, 12, 265294.

(38) Du, Q. M.S. Thesis, Chinese Academy of Sciences, RCEES, 1993.

(39) Nanjing Soil Institute. CAS, Soil Analysis; Shanghai Science \& Technology Editor; 1977; pp 132-135.

(40) Westall, J. FITEQL: a computer program for the determination of chemical equilibrium constants from experimental data; Report 82-01; Department of Chemistry, Oregon State University: Corvallis, 1982.

(41) Covs, J.; Sposito, G. Microql User's Manual; Department of Soil Science, University of California: Riverside, CA, 1984.

Received for review February 5, 1997. Revised manuscript received September 4, 1997. Accepted September 18, 1997. ${ }^{\otimes}$

\section{ES970098Q}

\footnotetext{
${ }^{\otimes}$ Abstract published in AdvanceACS Abstracts, October 15, 1997
} 